\title{
Iron-Catalyzed Asymmetric OH Bond Insertions
}

Metal-Catalyzed

Asymmetric

Synthesis and

Stereoselective

Reactions

Key words

spirobox ligands

OH insertion

$\alpha$-diazophenyl-

acetates

iron

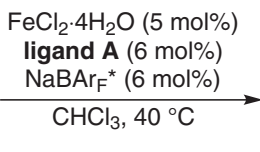<smiles>COC(=O)C(O)c1ccccc1</smiles>

$\mathrm{R}=\mathrm{Alk}, \mathrm{Bn}$, allyl, etc.

$86-95 \%$ yield, $89-99 \%$ ee

$\mathrm{FeCl}_{2} \cdot 4 \mathrm{H}_{2} \mathrm{O}(5 \mathrm{~mol} \%)$

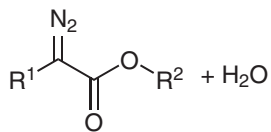
$\operatorname{NaBAr}_{F}^{*}(6 \mathrm{~mol} \%)$

$\mathrm{CHCl}_{3}, 40^{\circ} \mathrm{C}$<smiles>[R]OC(=O)C(O)[18OH]</smiles>

$66-93 \%$ yield $76-95 \%$ ee
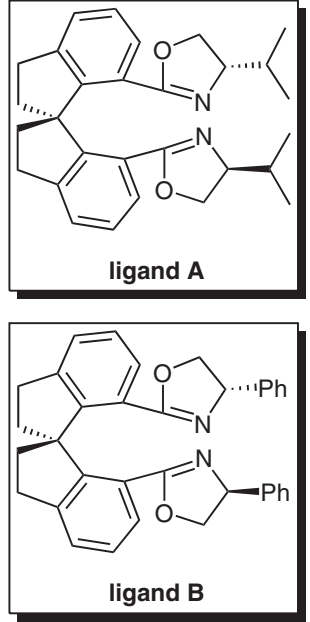

$\mathrm{R}^{1}=$ substituted $\mathrm{Ph}, \mathrm{Naph}$, thiophenyl, Me $\mathrm{R}^{2}=\mathrm{Me}$ or $\mathrm{Bn}$

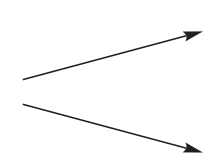

$86 \%$ yield, $89 \%$ ee intermediate to various synthetic targets<smiles>COC(=O)C(O)c1ccccc1Cl</smiles>

$92 \%$ yield, $95 \%$ ee intermediate to clopidogre<smiles>C[As]C</smiles><smiles>PN1CC2CO[C@H](c3ccccc3)C2=N1</smiles><smiles>C[C@H]1C(=O)N2C[C@H](c3ccccc3)O[C@H]12</smiles><smiles>C1=CC2(C=COC2c2ccccc2)OC1</smiles><smiles>CC(=O)OC(c1ccccc1Cl)N1CCc2sccc2C1</smiles><smiles>OC1CC=COC1c1ccccc1</smiles>
$93 \%$ ee
Significance: The authors developed a highly efficient iron-catalyzed protocol for the enantioselective carbene $\mathrm{OH}$ insertion. The reaction produces various $\alpha$-alkoxy and $\alpha$-hydroxyl arylacetates, which are quite useful synthetic intermediates, in very high yield and enantioselectivities.
Comment: This work features not only the high efficiency of iron-catalyzed carbene insertion to alcohol $\mathrm{OH}$ bonds, but also the insertion to a water $\mathrm{OH}$ bond to generate corresponding chiral $\alpha$-hydroxyl arylacetates in high yields and enantioselectivities. The results are better than the authors' previous work with copper catalysts (Angew. Chem. Int. Ed. 2008, 47, 932).

SYNFACTS Contributors: Hisashi Yamamoto, Zhi Li 